\title{
Perbandingan Inversi Reflektifitas Menggunakan Basis Pursuit Inversion dan Orthogonal Matching Pursuit pada Lapisan Tipis
}

\author{
Fatahillah A. D.* dan Winardhi S. \\ Teknik Geofisika, Fakultas Teknik Pertambangan dan Perminyakan, Institut Teknologi Bandung, \\ Jalan Ganesa No 10, Bandung, 40132 \\ *Email: dzikra.fatahillah09@gmail.com
}

Submit: 5 Maret 2017; Revised: 10 April 2017; Accepted: 20 April 2017

\begin{abstract}
Meningkatnya kebutuhan energi membuat diperlukannya eksplorasi migas untuk reservoar-reservoar tipis. Metode seismik memiliki peran penting dalam eksplorasi minyak dan gas bumi namun keterbatasan bandwith frekuensi menjadi salah satu permasalahan penampang seismik dalam meresolusi lapisan tipis. Terdapat beberapa metode yang dapat meresolusi lapisan tipis salah satunya basis pursuit inversion (BPI) namun proses BPI memerlukan waktu yang relatif lama. Terdapat metode orthogonal matching pursuit (OMP) yang juga dapat meresolusi lapisan tipis dengan waktu yang lebih singkat dari BPI. Penelitian ini mencoba menganalisis faktor-faktor yang berpengaruh dalam metode BPI dan OMP yaitu, regularization parameter (lambda), noise, ekstraksi wavelet, dan panjang matriks dictionary. Uji coba pada data sintetik membuktikan bahwa ekstraksi wavelet berpengaruh pada metode BPI dan diperoleh batasan kesalahan fasa dari $-14^{\circ}$ sampai $14^{\circ}$ pada model odd dan $-16^{\circ}$ sampai $16^{\circ}$ pada model even, batasan kesalahan frekuensi dari $-3 \mathrm{~Hz}$ sampai $3 \mathrm{~Hz}$ untuk model odd dan batasan keberadaan konvolusional noise sebesar $40 \%$ pada model even.Hasil uji coba data sintetik pada metode OMP menunjukkan bahwa OMP tidak memiliki ketahanan terhadap perubahan faktor ekstraksi wavelet dikarenakan tidak memiliki faktor denoising sehingga metode OMP kurang optimal untuk diterapkan pada data riil. Validasi metode BPI pada data riil dilakukan dengan membandingkan korelasi antara hasil BPI dengan data sumur. Hasil validasi menunjukkan metode BPI mampu meresolusi lapisan tipis dengan baik.
\end{abstract}

Kata kunci: Basis Pursuit Inversion, Orthogonal Matching Pursuit, Lapisan Tipis, Inversi Seismik.

\section{PENDAHULUAN}

Metode basis pursuit inversion yang digunakan oleh Zhang dan Castagna (2011) dapat merekonstruksi reflektivitas dari data seismik dan mampu meresolusi lapisan lebih baik dibandingkan sparse spike inversion. Dengan menggunakan teori dekomposisi dipol yang dilakukan oleh Chopra dkk (2006) metode basis pursuit inversion menyusun matriks kernel yang disebut matriks dictionary. Matriks dictionary tersebut kemudian akan dipecahkan untuk mendapatkan solusi reflektivitas menggunakan Basis Pursuit Decomposition (BPD), dimana pemrograman tersebut akan bersifat underdetermined. Sifat underdetermined berarti bahwa variabel yang diketahui akan jauh lebih sedikit dibandingkan dengan variable yang tidak diketahui yang menyebabkan solusi dari persamaan bersifat non-unique sehingga perlu dilakukan pemilihan solusi akhir yang paling memenuhi kriteria untuk mengatasi sifat non-unique. Kriteria tersebut, yaitu: (1) cocok dengan data sumur; dan (2) memenuhi suatu constraint yang ditentukan untuk mengatasi sifat non-unique. Pendekatan terhadap data seismik akan dilakukan oleh matriks dictionary yang merupakan hasil susunan dari dekomposisi dipol yang dikonvolusikan dengan wavelet. Penggunaan wavelet dan juga kualitas data seismik dapat mempengaruhi hasil basis pursuit. Faktor-faktor tersebut bisa menimbulkan kesalahan pada hasil akhir basis pursuit sehingga sebelum menggunakan metode basis pursuit pada data riil perlu dilakukannya percobaan untuk mengetahui threshold atau batasan terhadap faktor-faktor tersebut.

\section{METODE}

\subsection{Model Konvolusi}

Setiap lapisan diasumsikan memiliki masing-masing sifat fisik uniform yang berbeda, dan setiap batas lapisan mempunyai reflection coefficient (RC). Data seismik post-stack memberikan gambaran dari lapisan bawah permukaan yang mendeskripsikan distribusi spatial dari batas-batas lapisan tersebut. Setiap trace seismic post-stack merupakan hasil konvolusi wavelet dengan koefisien refleksi (RC) dan ditambahkan dengan noise. Persamaan matematik dari konvolusi $\mathrm{RC}$ dan wavelet dapat dituliskan sebagai berikut :

$$
\begin{gathered}
s(t)=w(t) *(t)+n(t) \\
s(t)=\int w(t-\tau) r(\tau) d \tau+n(t) \\
d=G m+n
\end{gathered}
$$


Trace seismic dinyatakan dalam $s(t)$, wavelet dinyatakan dalam $w(t)$, reflektivitas dinyatakan dalam $(r(t), *$ adalah simbol operator konvolusi dan noise dinyatakan dalam $n(t)$. Operasi konvolusi tersebut kemudian dirubah menjadi perkalian vektor reflektivitas dengan suatu matriks kernel. Ilustrasi konvolusi dalam perkalian matriks dapat ditunjukkan seperti persamaan (3) dimana $d$ adalah data seismogram, $m$ adalah diagonal wavelet matriks, $G$ adalah koefisien refleksi, dan $n$ adalah matriks noise.

\section{$2.2 \quad L_{p}$ Norm Constraint}

Persamaan (3) memperlihatkan hubungan antara data obsevasi seismogram, diagonal wavelet matriks, koefisien refleksi, dan noise. Koefisien refleksi merupakan variabel yang diinginkan dari variabel diketahui data seismogram dan didapatkan setelah memecahkan persamaan (3) menjadi persamaan berikut:

$$
m=G^{-1} * d
$$

Inverse matriks $G$ akan memiliki sifat illness dan mempunyai beberapa masalah yaitu, non-uniqueness, kurangnya resolusi, ketidakstabilan, dan kapabilitas inferior denoising. Sehingga solusi least-square harus memenuhi konstrain yang memenuhi persamaan berikut:

$$
\min \|d-G m\|_{2}+\lambda \jmath(m)
$$

Dengan $\jmath(m)$ adalah $\lambda$-weighted global constraint function, berisi informasi apriori dari model. lambda $\lambda$ adalah faktor damping yang mengontrol noise.

\subsection{Basis Pursuit Inversion}

Basis Pursuit Inversion (BPI) merupakan salah satu metode dekomposisi sinyal dalam overcomplete dictionary yang menggunakan convex optimization. Dictionary yang digunakan berisi banyak kemungkinan bentuk wavelet dari lapisan tipis sampai ketebalan tuning. Kemudian matriks tersebut didekomposisi dengan menggunakan minimum $L_{1}$ norm. Metode BPI memiliki sifat unconstraint sehingga perlu menggunakan suatu parameter, yaitu regularization parameter atau lambda yang divalidasi dengan data sumur.

\subsection{Dekomposisi Dipol}

Lapisan tipis bisa dianggap sebagai suatu pasangan reflektor yang dituliskan sebagai dua fungsi impuls $c \delta(t)$ dan $d \delta(t+\Delta t)$. Dekomposisi dipol akan mendekomposisi suatu pasangan reflektor menjadi pasangan reflektor genap $r_{e}$ dan pasangan reflektor ganjil $r_{o}((?))$. Dalam matematis dekomposisi dipol dapat dituliskan dengan persamaan berikut:

$$
\begin{gathered}
c \delta(t)+d \delta(t+\Delta t)=a r_{e}+b r_{o} \\
r_{e}=\delta(t)+\delta(t+\Delta t) \\
r_{o}=\delta(t)-\delta(t+\Delta t)
\end{gathered}
$$

\subsection{Matriks Dictionary}

Matriks dictionary merupakan kumpulan dari reflektor dipol yang diberikan interval yang semakin bertambah dari ketebalan nol hingga suatu ketebalan tuning. Pasangan reflektivitas akan bergeser sesuai sampling sebanyak $m \Delta t$, dimana $m$ bernilai mulai dari sample pertama sampai terakhir. Pasangan reflektivitas dalam wedge model dapat dituliskan sebagai berikut:

$$
\begin{aligned}
& r_{e}(t, m, n, \Delta t)=\delta(t-m \Delta t)+\delta(t-m \Delta t-n \Delta t) \\
& r_{o}(t, m, n, \Delta t)=\delta(t-m \Delta t)+\delta(t-m \Delta t-n \Delta t)
\end{aligned}
$$

Sample rate $\Delta t$ merupakan sampling yang digunakan, $n$ merupakan suatu bilangan yang bertambah dari nol hingga suatu ketebalan tuning. Deret reflektivitas dianggap sebagai penjumlahan wedge even dan wedge odd dengan time shift atau pergeseran, atau secara matematis dapat dituliskan sebagai berikut:

$r(t)=\sum_{n=1}^{N} \sum_{n=1}^{M}\left(a_{n, m} \times r_{e}(t, m, n, \Delta t)+n_{n, m} \times r_{o}(t, m, n, \Delta t)\right)$

Persamaan (12) adalah deret reflektivitas yang merupakan matriks dictionary jika dikonvolusikan dengan wavelet akan menghasilkan tras seismik.

$s(t)=\sum_{n=1}^{N} \sum_{n=1}^{M}\left(a_{n}, m \times w r_{e}(t, m, n, \Delta t)+n_{n}, m \times w r_{o}(t, m, n, \Delta t)\right)$

Persamaan (12) jika dinyatakan dalam bentuk matriks persamaan (3) maka $d$ adalah $s(t), m$ merupakan matriks koefisien even dan odd, dan $G$ adalah hasil perkalian reflektor even dan odd yang dikonvolusikan dengan wavelet.

\subsection{Orthogonal Matching Pursuit}

OMP merupakan algoritma yang bersifat greedy dalam menemukan sparse dari suatu sinyal yang diberikan. Algoritma OMP ini mencoba menemukan atom atau basis vektor terbaik secara iterative, sehingga dalam setiap iterasi eror dalam representasi semakin berkurang. Pemilihan atom dari dictionary memiliki proyeksi terbesar dan mutlak pada vektor eror yang menunjukkan bahwa jika memilih atom yang menambahkan informasi maksimum dapat secara maksimal mengurangi kesalahan atau eror dalam rekonstruksi sinyal vektor $y$ dan dictionary $D$, algoritma OMP digunakan untuk mendapatkan nilai dari vektor $x$ dalam tiga langkah, yaitu:

(i) Memilih atom yang memiliki proyeksi maksimal pada residunya.

(ii) Perbarui $x_{i}=\left\|y-D x_{i}\right\|$.

(iii) Perbarui residu $r_{k}=y-D_{k} x_{k}$.

\subsection{Pemrograman Linier}

Persamaan yang didapatkan dari persamaan (3) dan (12) dapat diselesaikan dengan proses inversi menggunakan $L_{1-}$ regularized least square (L1-LS). L1-LS mencari solusi terbaik dari semua solusi yang ada didalam matriks dictionary 


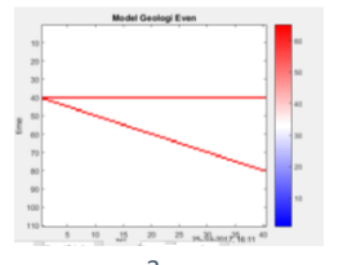

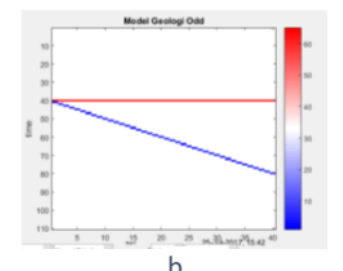

Gambar 1. Model koefisien refleksi even ((a) dan odd ((b). Warna biru menunjukkan nilai negatif dan warna merah menunjukkan nilai positifuntuk model koefisien refleksi.

untuk memperoleh $m$ atau koefisien even dan odd. Penyelesaian $L_{1}$-least square menggunakan algoritma basis pursuit, yaitu algoritma primal seperti persamaan (13) dan dual seperti persamaan (14).

$$
\min c^{T} x \text { subjectto } A x=b, x \geq 0
$$

$$
\max b^{T} y \text { subjectto } A^{T} y+z=c, z \geq 0
$$

Solusi paling baik dari algoritma basis pursuit adalah solusi yang memenuhi tiga syarat berikut:

(i) Primalinfeasibility, $\|b-A x\|_{2}$, minimum.

(ii) Dual infeasibility, $\left\|c-z+A^{T} y\right\|_{2}$, minimum.

(iii) Duality gap, $c^{T} x-b^{T} y$, minimum.

Ketiga syarat tersebut diselesaikan dengan cara simultan yang kemudian memperoleh koefisien even dan koefisien odd. Koefisien tersebut akan dikalikan dengan matriks dictionary yang belum dikonvolusikan dengan wavelet untuk mendapatkan reflektivitas hasil basis pursuit inverion (BPI).

\section{DATA DAN PENGOLAHAN DATA}

Penelitian ini menggunakan data sintetik untuk menguji faktor-faktor yang mempengaruhi hasil BPI dan OMP. Ada dua model sintetik yang dibuat yaitu model even dan model odd. Model even merupakan model geologi yang memiliki bentuk wedge dan koefisien refleksi dengan tanda sejenis (positif atau negatif) antara batas lapisan atas dan batas lapisan bawah. Model odd memiliki tanda yang berbeda jenis antara batas lapisan atas dan batas lapisan bawah. Kedua model tersebut akan ditambahkan konvolusional noise dan additive noise. Konvolusional noise akan ditambahkan ketika reflektivitas belum dikonvolusi dengan wavelet, sedangkan additive noise ditambahkan ketika reflektivitas telah dikonvolusi dengan wavelet. Besar variabel yang diuji akan dirubah-rubah, sedangkan variabel lainnya tidak diubah. Wavelet yang digunakan adalah wavelet ricker dengan frekuensi $30 \mathrm{~Hz}$. Gambar 1. menunjukkan model geologi odd dan even.

Pada Gambar 2. menunjukkan model post-stack seismik sintetik. Pada penampang seismik even respon gelombang terdapat efek saling menguatkan atau biasa disebut efek konstruktif yang menyebabkan kedua reflektor terlihat semakin dekat dari posisi sebenarnya.

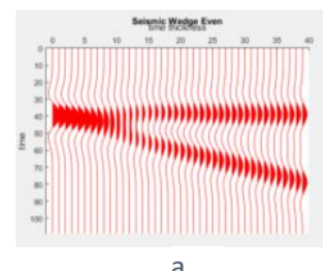

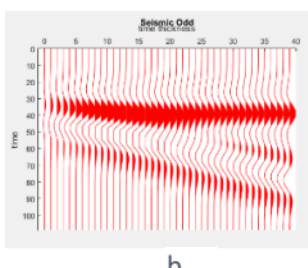

Gambar 2. Penampang post stack seismik even (a) dan odd (b). Penampang menggunakan wavelet ricker $30 \mathrm{~Hz}$ dan panjang 110 ms.

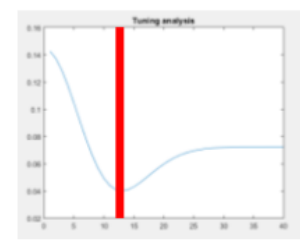

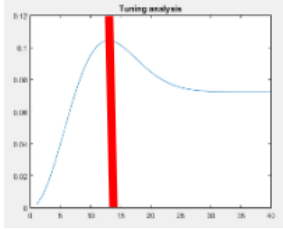

b
Gambar 3. Analisa tunning pada model even (a) dan model odd (b).
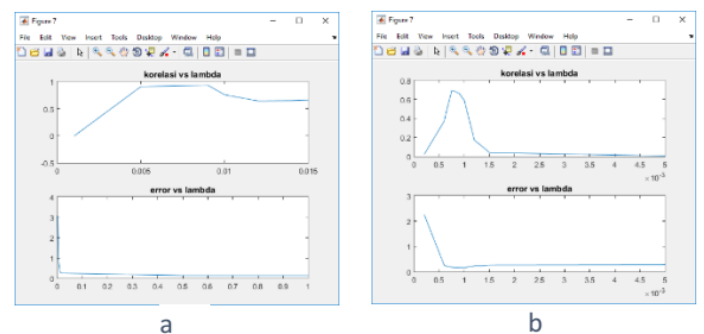

Gambar 4. Hasil plot korelasi dan error BPI tras ketigabelas pada setiap lambda untuk model even (a) dan model odd (b).

\subsection{Perbandingan Hasil BPI dan OMP pada Model Even dan Model Odd}

Gambar 3. menunjukkan tuning terjadi pada ketebalan 10 ms. Setelah dilakukan analisis tuning, dilakukan pengujian lambda dan lambda yang dipilih bernilai 0,009 untuk even dan 0,014 untuk odd. Gambar 4. adalah plot hasil korelasi dan error BPI pada tras ke-tigabelas pada setiap lambda yang diujikan. Pada pengujian lambda dapat dilihat bahwa lambda terbaik adalah lambda yang memiliki korelasi paling tinggi dan error paling rendah. Lambda dan tuning yang diperoleh kemudian digunakan pada inversi BPI dan OMP untuk diterapkan pada data seismik sintetik.

Gambar 5. dan Gambar 6. menunjukkan hasil inversi BPI dan OMP pada data seismik model even dan model odd. Pada model even terlihat inversi BPI dan OMP mampu meresolusi sampai dengan ketebalan $1 \mathrm{~ms}$ sedangkan pada model odd inversi BPI hanya dapat meresolusi sampai dengan ketebalan $6 \mathrm{~ms}$ namun inversi OMP dapat meresolusi hingga ketebalan $2 \mathrm{~ms}$. Perbedaan hasil inversi BPI dan OMP dalam meresolusi model even dan model odd disebabkan oleh sifat interferensi gelombang pada model even yang saling menguatkan atau konstruktif sehingga BPI dan OMP menjadi lebih mudah dalam mencari posisi reflek- 


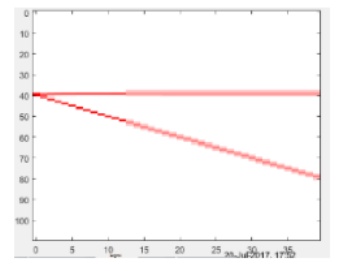

a

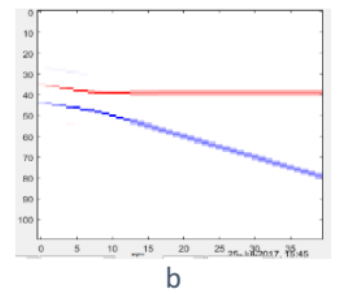

Gambar 5. Koefisien refleksi hasil BPI model even (a) dan model odd (b).
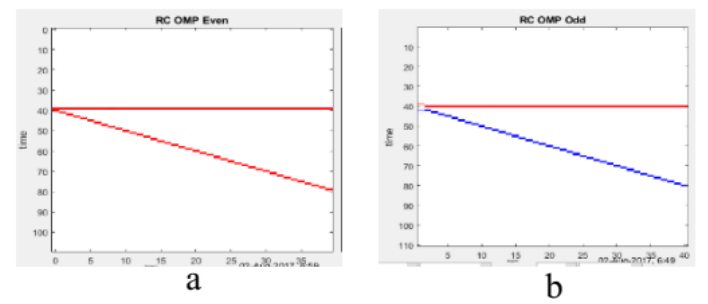

Gambar 6. Koefisien refleksi hasil OMP model even (a) dan model odd (b).

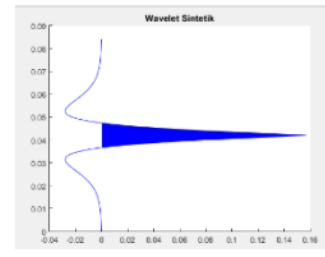

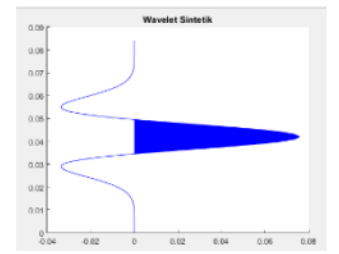

b
Gambar 7. wavelet wavez dan ricker.

tor yang sesuai. Pada model odd terdapat sifat interferensi gelombang yang saling melemahkan atau destruktif sehingga inversi BPI dan OMP akan lebih sulit unntuk mencari posisi reflektor yang sesuai. Hal tersebut menunjukkan bahwa inversi BPI dan OMP lebih mudah meresolusi pasangan reflektor even daripada odd dan kemudian akan dijadikan pertimbangan dalam proses pengolahan data real.

\subsection{Hasil BPI dan Analisis Terhadap Penggunaan Wavelet Wavez}

Data seismik sintetik diujikan menggunakan wavelet wavez dan ricker. Pengujian ini dilakukan karena hasil BPI pada model odd tidak dapat meresolusi secara maksimal. Bentuk dari wavelet wavez dan ricker ditunjukkan oleh Gambar 7 . Gambar 9. merupakan hasil inversi BPI pada model odd dengan wavelet wavez dan ricker. Model odd hasil inversi BPI dengan menggunakan wavelet wavez dapat meresolusi lapisan tipis tuning thickness dengan sangat baik. Hal tersebut dikarenakan bentuk dari wavez yang sangat spike dengan spectrum yang memiliki bandwidth yang luas. Namun data seismik pada kondisi nyata tidak memiliki wavelet seperti wavez sehingga harus dilakukan whitening pada spectrum wavelet ricker untuk mendekati bentuk spectrum

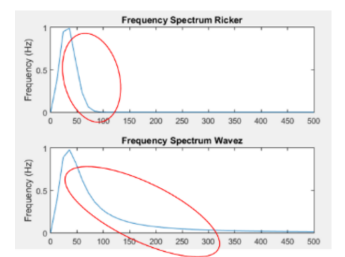

Gambar 8. Spectrum amplitude wavelet ricker (atas) dan wavelet wavez (bawah).

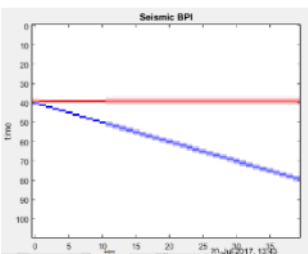

a

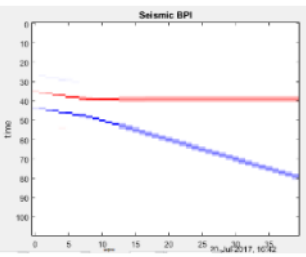

$\mathrm{b}$
Gambar 9. Koefisien refleksi model odd hasil BPI dengan wavelet wavez (a) dan ricker (b).
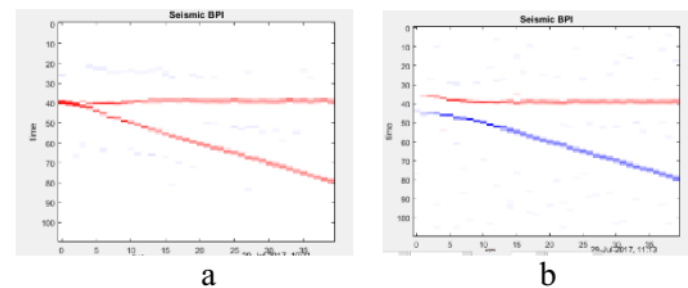

Gambar 10. Koefisien refleksi hasil BPI dengan konvolusional noise $10 \%$ model even (a) dan model odd (b).

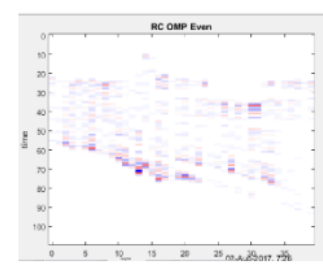

a

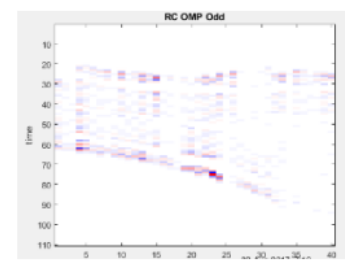

b
Gambar 11. Koefisien refleksi hasil OMP dengan konvolusional noise $10 \%$ model even (a) dan model odd (b).

wavelet wavez. Namun, karena keterbatasan waktu, percobaan tersebut tidak dilakukan pada penelitian ini.

\subsection{Hasil BPI dan OMP serta Analisis Terhadap Konvolusional Noise}

Gambar 10. Sampai Gambar 15. adalah hasil inversi BPI dan OMP dengan noise 10\%, 25\%, 50\%. Terlihat semakin bertambahnya noise maka hasil inversi BPI model even dan model odd semakin tidak mendekati kondisi sebenarnya dikarenakan proses inversi BPI yang menganggap sinyal noise sebagai informasi reflektor. Namun pada model even dan model odd hasil inversi OMP memiliki tingkat sensitif 


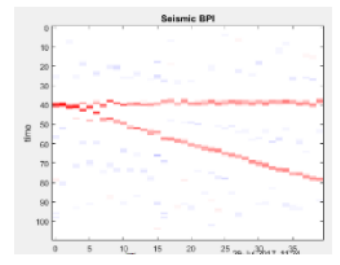

a

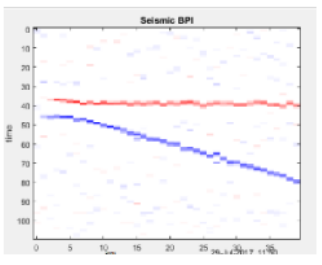

$\mathrm{b}$

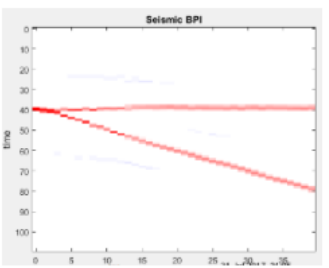

a

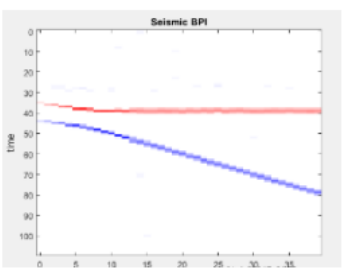

$\mathrm{b}$
Gambar 12. Koefisien refleksi hasil BPI dengan konvolusional noise $25 \%$ model even (a) dan model odd (b). a

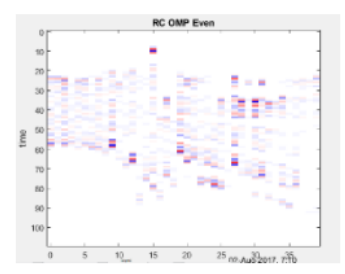

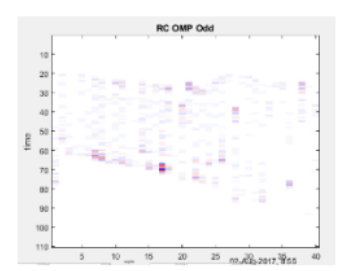

b
Gambar 13. Koefisien refleksi hasil OMP dengan konvolusional noise $25 \%$ model even (a) dan model odd (b).

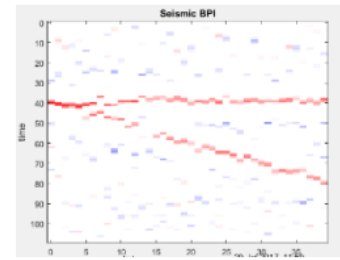

a

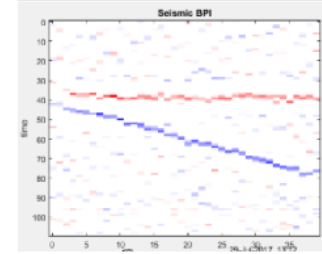

b
Gambar 14. Koefisien refleksi hasil BPI dengan konvolusional noise $50 \%$ model even (a) dan model odd (b).

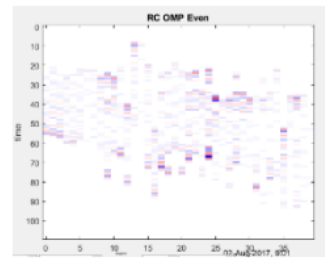

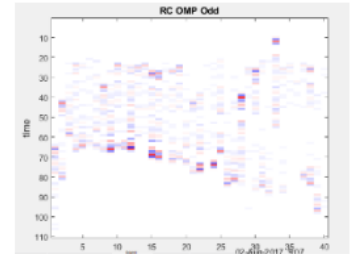

b
Gambar 15. Koefisien refleksi hasil OMP dengan konvolusional noise $50 \%$ model even (a) dan model odd (b).

yang tinggi kepada penambahan noise. Hasil inversi BPI dan OMP pada konvolusional noise juga menunjukkan bahwa hasil model odd memiliki korelasi yang lebih baik dibandingkan model even. Hal tersebut menunjukkan bahwa inversi BPI dan OMP pada model odd lebih memiliki ketahanan terhadap noise dibandingkan model even.
Gambar 16. Koefisien refleksi hasil BPI dengan additive noise $10 \%$ model even (a) dan model odd (b).

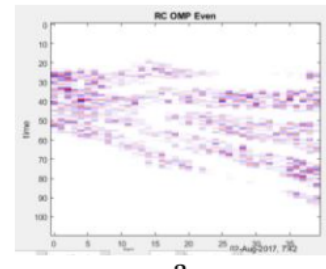

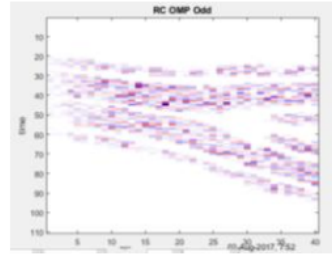

$\mathrm{b}$
Gambar 17. Koefisien refleksi hasil OMP dengan additive noise $10 \%$ model even (a) dan model odd (b).

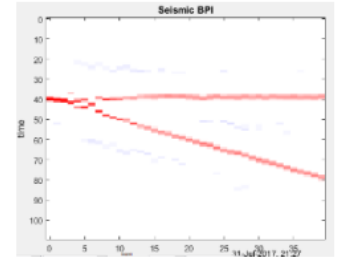

a

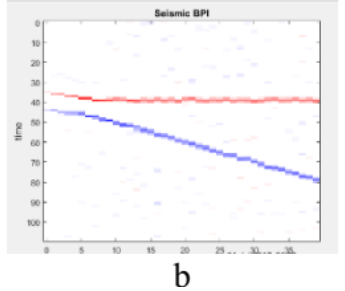

$\mathrm{b}$
Gambar 18. Koefisien refleksi hasil BPI dengan additive noise $25 \%$ model even (a) dan model odd (b).

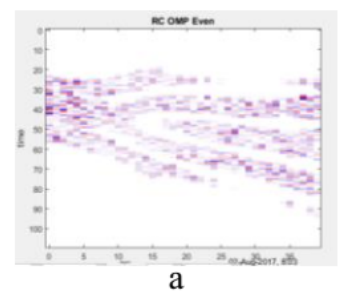

$\mathrm{a}$

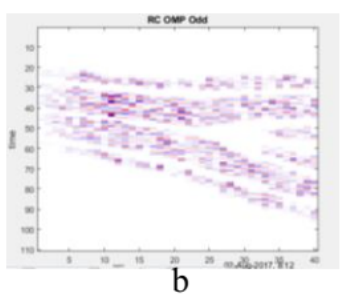

$\mathrm{b}$
Gambar 19. Koefisien refleksi hasil OMP dengan additive noise $25 \%$ model even (a) dan model odd (b).
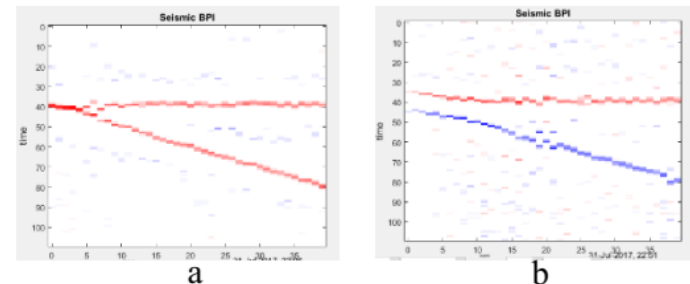

Gambar 20. Koefisien refleksi hasil BPI dengan additive noise $50 \%$ model even (a) dan model odd (b). 


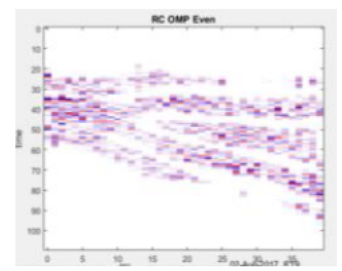

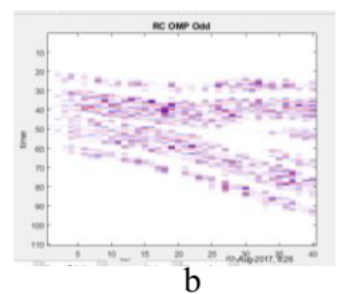

$\mathrm{b}$

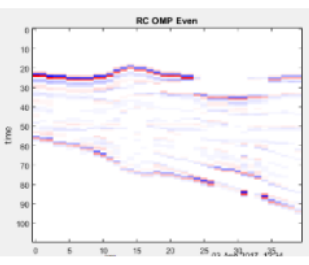

a

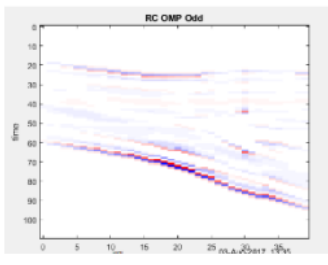

$\mathrm{b}$
Gambar 21. Koefisien refleksi hasil OMP dengan additive noise $50 \%$ model even (a) dan model odd (b).

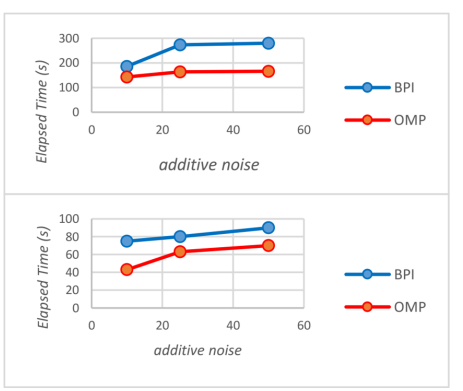

Gambar 22. Grafik hubungan antara elapsed time dan additive noise BPI dan OMP pada model even (atas) dan model odd (bawah).

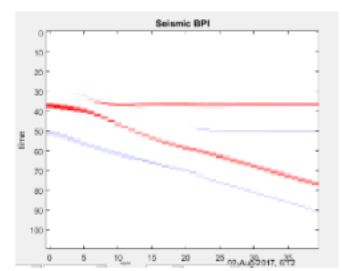

a

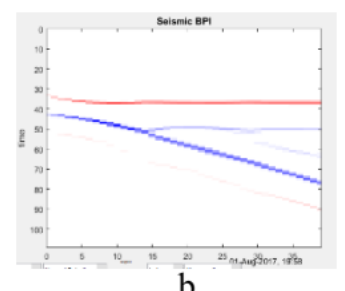

b
Gambar 23. Koefisien refleksi hasil BPI dengan mis-phase $-30^{\circ}$ model even (a) dan model odd (b).

\subsection{Hasil BPI dan OMP serta Analisis Terhadap emphAdditive Noise}

Gambar 16. Sampai Gambar 21. adalah hasil inversi BPI dan OMP pada additive noise. Seperti konvolusional noise,noise pada sinyal akan dianggap sebagai reflektor yang menyebabkan jika semakin besarnoise akan semakin buruk juga hasil inversinya. Pada additive noise juga dapat terlihat model odd lebih tahan terhadap noise dibandingkan dengan model even.

Gambar 22. menunjukkan hubungan antar elapsed time dan additive noise terhadap hasil inversi BPI dan OMP dengan data sintetik pada model odd dan model even. Gambar 22. Sebagai salah satu contoh yang menunjukkan waktu yang dibutuhkan dalam proses inversi OMP lebih cepat dari pada BPI. Hal ini berlaku juga pada pengujian konvolusional noise.
Gambar 24. Koefisien refleksi hasil OMP dengan mis-phase $-5^{\circ}$ model even (a) dan model odd (b).

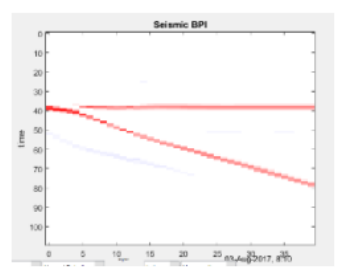

a

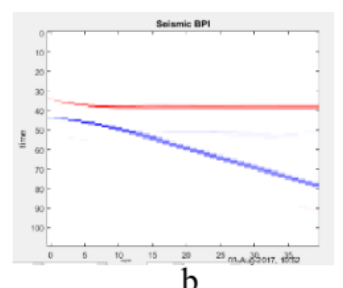

b
Gambar 25. Koefisien refleksi hasil BPI dengan mis-phase $-10^{\circ}$ model even (a) dan model odd (b).

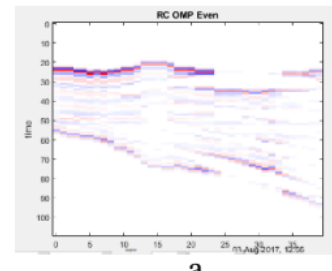

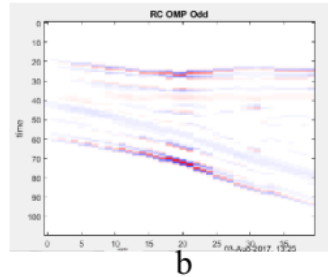

b
Gambar 26. Koefisien refleksi hasil OMP dengan mis-phase $-1^{\circ}$ model even (a) dan model odd (b).

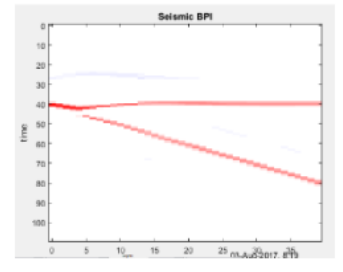

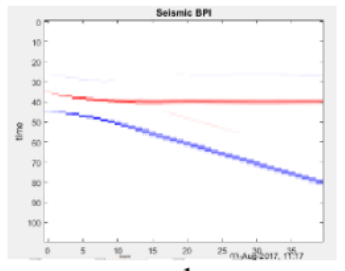

b
Gambar 27. Koefisien refleksi hasil BPI dengan mis-phase $10^{\circ}$ model even (a) dan model odd (b).
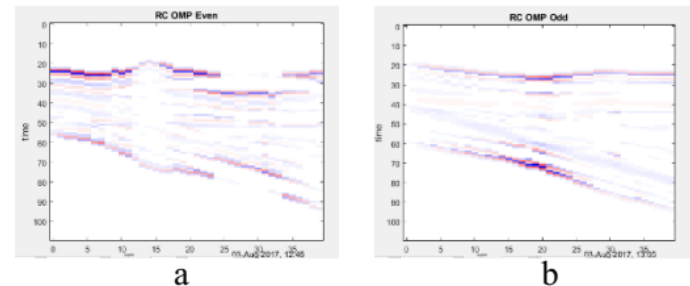

Gambar 28. Koefisien refleksi hasil OMP dengan mis-phase $1^{\circ}$ model even (a) dan model odd (b). 


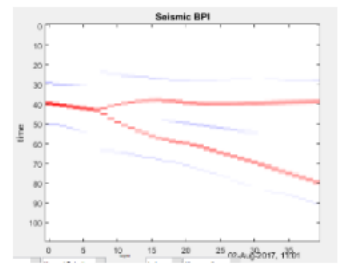

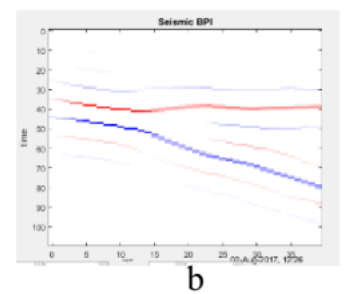

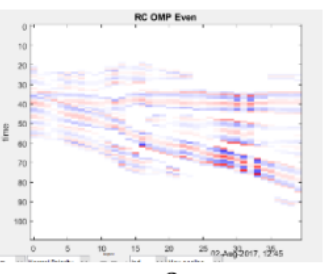

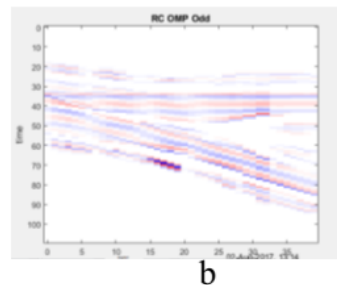

Gambar 32. Hasil OMP dengan mis-frekuensi $-2 \mathrm{~Hz}$ model even (a) dan model odd (b).

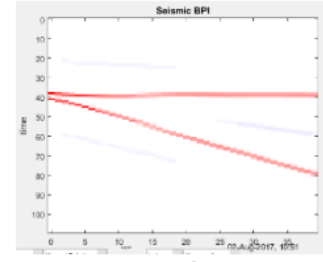

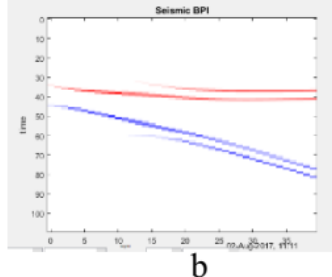

Gambar 30. Hasil OMP dengan mis-frekuensi -4 Hz model even (a) dan model odd (b).

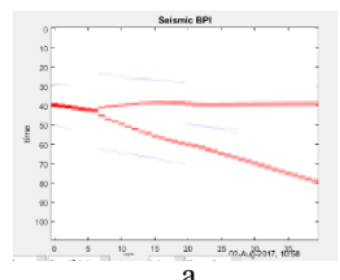

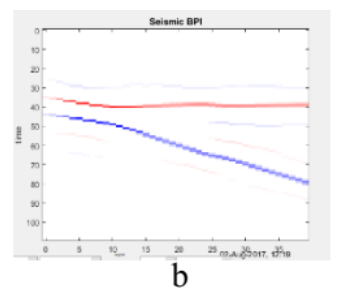

b
Gambar 31. Hasil BPI dengan mis-frekuensi -2 Hz model even (a) dan model odd (b).

\subsection{Hasil BPI dan OMP serta Analisis Terhadap misphase wavelet}

Gambar 23. sampai Gambar 28. menggambarkan hasil BPI dan OMP dengan perbedaan fasa ekstraksi wavelet dan wavelet pada penampang seismik. Diujikan mis-phase dari 30o sampai 30o pada BPI dan -5o sampai 5o pada OMP. Terlihat bahwa semakin besar misphase yang diberikan maka hasil BPI dan OMP akan semakin tidak mendekati kondisi riil. Selain itu, dapat terlihat seolah-olah terdapat reflektorreflektor yang bukan reflektor sebenarnya akibat dari proses BPI dan OMP yang menganggap puncak dan gelombang tersebut sebagai informasi reflektor.

\subsection{Hasil BPI dan OMP serta Analisis Terhadap Mis frekuensi}

Gambar 29. Sampai Gambar 36. adalah hasil percobaan BPI dan OMP yang diberikan perbedaan frekuensi ekstraksi wavelet dengan wavelet pada penampang seismik atau mis-frekuensi. mis-frekuensi berkisar dari - $4 \mathrm{~Hz}$ sampai $4 \mathrm{~Hz}$. Gambar-gambar tersebut menunjukkan bahwa semakin besar frekuensi maka hasil BPI dan OMP semakin tidak mendekati kondisi sebenarnya. Hal tersebut dise-
Gambar 33. Hasil BPI dengan mis-frekuensi $2 \mathrm{~Hz}$ model even (a) dan model odd (b)
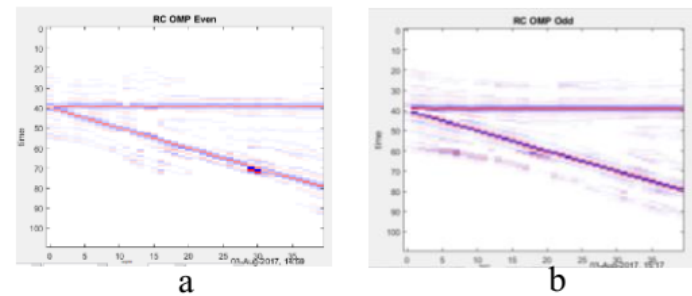

Gambar 34. Hasil OMP dengan mis-frekuensi $2 \mathrm{~Hz}$ model even (a) dan model odd (b)
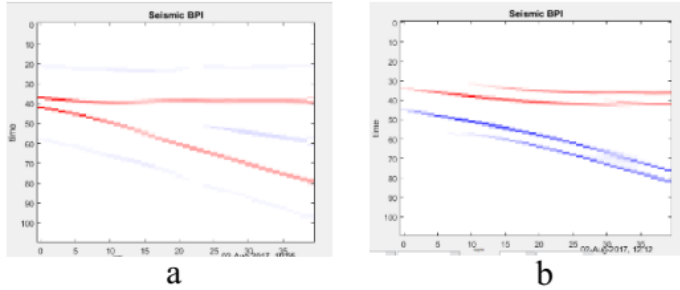

Gambar 35. Hasil BPI dengan mis-frekuensi $4 \mathrm{~Hz}$ model even (a) dan model odd (b)

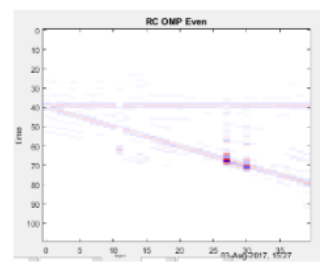

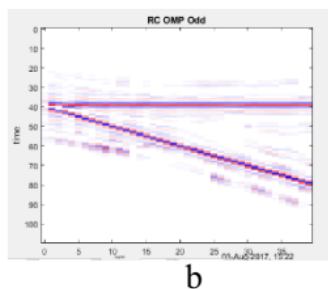

Gambar 36. Hasil OMP dengan mis-frekuensi $4 \mathrm{~Hz}$ model even (a) dan model odd (b). 


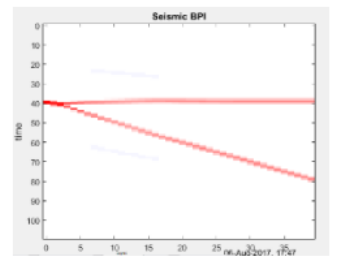

a

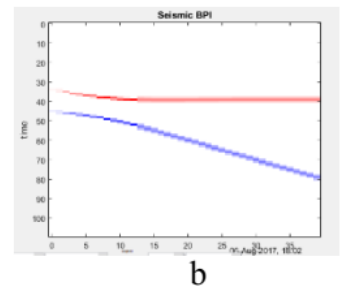

b
Gambar 37. Hasil BPI optimasi panjang matriks dictionary $\frac{1}{2}$ tunning pada model even (a) dan model odd (b). $\mathrm{a}$

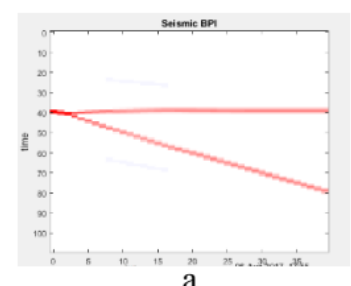

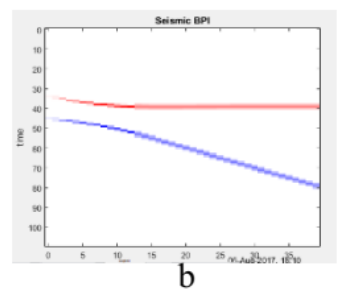

Gambar 38. Hasil BPI optimasi panjang matriks dictionary $\frac{3}{4}$ tunning pada model even (a) dan model odd (b).

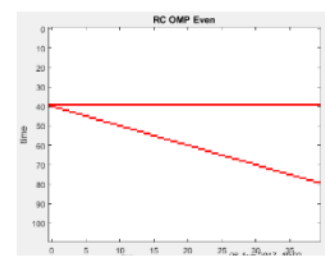

a

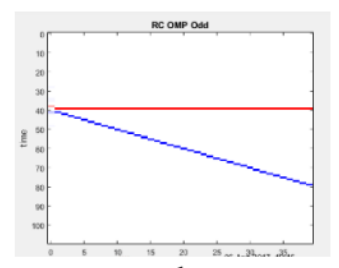

b
Gambar 39. Hasil OMP optimasi panjang matriks dictionary $\frac{1}{2}$ tunning pada model even (a) dan model odd (b).

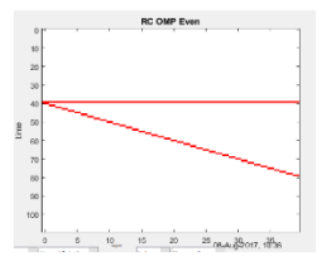

$\mathrm{a}$

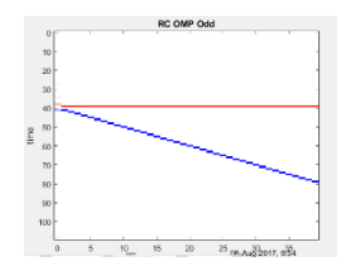

b
Gambar 40. Hasil OMP optimasi panjang matriks dictionary $\frac{3}{4}$ tunning pada model even (a) dan model odd (b).

babkan karena frekuensi menentukan suatu panjang gelombang dan bentuk gelombangnya sendiri.

\subsection{Hasil BPI dan OMP serta Analisis Terhadap Panjang Matriks Dictionary}

Hasil BPI dengan panjang matriks dictionary $\frac{1}{2}$ tunning dan $\frac{3}{4}$ tunning ditunjukkan dengan Gambar 37. dan Gambar 38 . Sedangkan hasil OMP dengan panjang matriks dictionary $\frac{1}{2}$ tunning dan $\frac{3}{4}$ tunning ditunjukkan dengan Gambar 39 . dan Gambar 40.

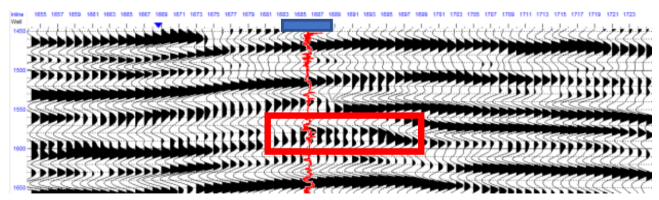

Gambar 41. Penampang post-stack seismik cross-line 3724 dan twt 1450-1650 ms.
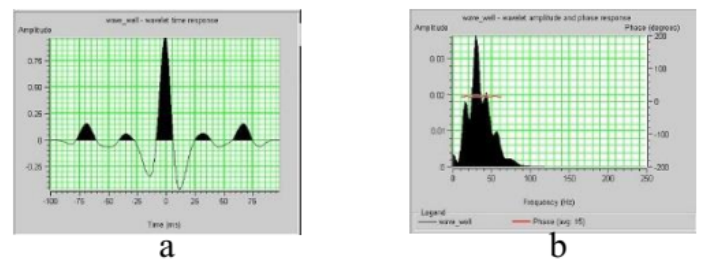

Gambar 42. Wavelet hasil ekstraksi sumur dengan panjang 100 ms (a) pada domain waktu dan pada domain frekuensi (b).

\section{APLIKASI METODE BPI PADA DATA RIIL}

\subsection{Pemilihan Zona Target}

Inversi BPI akan dilakukan pada penampang post-stack di cross-line 3724, in-line 1680-1710, dan time 1450- $1650 \mathrm{~ms}$. Zona target penelitian yang dipilih memiliki wedge model even atau memiliki reflektor dengan tanda yang sama. Akan tetapi terlihat bahwa penampang seismik lapisan ini semakin tipis semakin menghilang seperti ditunjukkan oleh Gambar 41.

\subsection{Ekstraksi wavelet}

Wavelet yang digunakan pada penelitian ini merupakan wavelet hasil dari ekstraksi sumur. Sebelum melakukan ekstraksi wavelet, dilakukan proses well to seismic tie untuk mendapatkan korelasi yang baik antara sumur dengan penampang seismik. Proses well to seismic tie awalnya menggunakan wavelet hasil statistik kemudian baru dilakukan proses ekstraksi menggunakan sumur. Wavelet ekstraksi sumur yang diperoleh ditunjukkan oleh Gambar 42 .

\subsection{Well to Seismic tie}

Aplikasi dari proses well to seismic tie perlu diterapkan untuk mendapatkan hasil ekstraksi wavelet yang baik serta penentuan nilai parameter lambda yang baik. Dalam penelitian ini dihasilkan well to seismic tie menggunakan ekstraksi wavelet sumur dengan nilai korelasi 0,883. Gambar 43. adalah gambaran well to seismic tie.

\subsection{Pencarian Lambda Optimal}

Uji lambda yang dilakukan pada data real bervariasi yaitu dari 0,1 sampai 5 dengan kenaikan 0,1. Gambar 44. menunjukkan hasil korelasi dari pengujian setiap lambda. lambda yang digunakan adalah lambda yang menghasilkan korelasi yang paling maksimum, yaitu 0,7 .

Lambda 0,7 dapat dikatakan optimal karena menghasilkan nilai korelasi antara hasil BPI dengan data sumur sebesar 


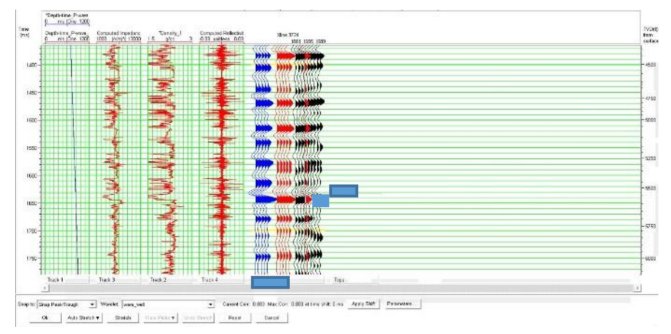

Gambar 43. Well to seismic tie dengan wavelet sumur.

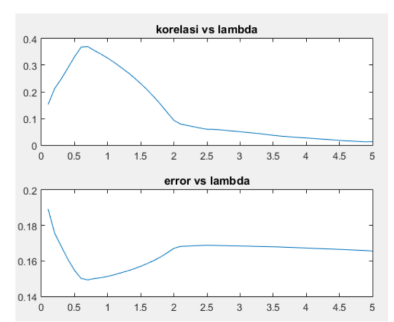

Gambar 44. Hasil plot korelasi dengan lambda (atas) dan hasil plot error dengan lambda (bawah).
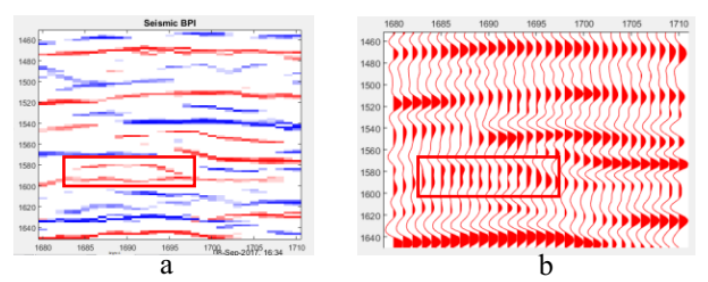

Gambar 45. Koefisien refleksi hasil BPI (a) dan penampang post-stack seismik (b) in-line 1680-1710 ms cross-line 3724 time 1450- $1650 \mathrm{~ms}$.

0,3699 dan nilai error 0,2366. lambda 0,7 kemudian digunakan untuk inversi BPI untuk setiap tras dari cross-line 3724 dan in-line 1680-1710.

\subsection{Hasil post-stack BPI}

Zona target lapisan tipis ditunjukkan pada daerah kotak merah di Gambar 45. Hasil inversi BPI pada penelitian ini dapat meresolusi koefisien refleksi pada lapisan tipis dengan keterbatasan kemenerusan yang tidak terlalu baik. Terdapat faktor-faktor yang melebihi batas atau tresshold yang mempengaruhi resolusi inversi BPI seperti mis-frekuensi, misphase, noise dan perubahan wavelet terhadap kedalaman.

\section{KESIMPULAN DAN SARAN}

\subsection{Kesimpulan}

Kesimpulan dari penerapan metode inversi BPI dan OMP pada data sintetik menunjukkan beberapa hal berikut:

(i) BPI dan OMP dapat meresolusi lapisan tipis dengan baik pada data sintetik yang memiliki signal to noise ratio $100 \%$. (ii) OMP mampu meresolusi reflektifitas odd lebih baik dari pada BPI pada data sintetik yang memiliki signal to noise ratio $100 \%$.

(iii) lambda merupakan faktor penting dalam BPI. Semakin besar lambda maka akan menghasilkan reflektor yang lebih sparse, sedangkan semakin kecil akan menghasilkan reflektor yang lebih dense. lambda juga dapat digunakan untuk mengoptimalkan hasil inversi pada penampang post-stack yang memiliki noise.

(iv) Pada BPI, keberadaan additive noise dan kovolusional noise akan dianggap sebagai informasi reflektor baik pada model even dan model odd. Pada pasangan reflektor even mempunyai sensitivitas yang lebih tinggi dibandingkan reflekto odd.

(v) Pada OMP, hasil resolusi baik pada model even dan model odd menunjukkan tidak memiliki ketahanan terhadap uji fasa, uji frekuensi, additive noise dan kovolusional noise. Hal ini disebabkan karena tidak adanya parameter yang dapat meredam keberadaan noise pada OMP.

(vi) Perbedaan fasa antara wavelet ekstraksi dan wavelet pada penampang seismik pada BPI akan menghasilkan kesalahan dekomposisi reflektor yang cukup signifikan. Kesalahan fasa wavelet yang masih dapat ditoleransi adalah +14o dan -140 untuk model odd dan -160 sampai 16o untuk model even. Hal tersebut menjadikan BPI sensitif terhadap ketepatan fasa wavelet ekstraksi.

(vii) Perbedaan frekuensi antara wavelet ekstraksi dan wavelet pada penampang seismik pada BPI akan menghasilkan kesalahan dekomposisi reflektor yang cukup signifikan. Kesalahan fasa wavelet yang masih dapat ditoleransi adalah $-3 \mathrm{~Hz}$ dan $3 \mathrm{~Hz}$. Hal tersebut membuktikan BPI sensitif terhadap ketepatan frekuensi wavelet.

(viii) Panjang matriks dictionary pada metode BPI dan OMP akan berpengaruh pada waktu proses perhitungan. Pengurangan panjang matriks dictionary tidak berpengaruh terlalu signifikan sehingga dapat dilakukan optimasi panjang matriks dictionary untuk mempersingkat waktu proses perhitungan baik BPI maupun OMP.

(ix) Penggunaan wavelet wavez dapat menghasilkan resolusi reflektivitas odd pada BPI lebih baik dari pada menggunakan wavelet ricker. Namun data seismik pada kondisi nyata tidak memiliki wavelet seperti wavez sehingga harus dilakukan enhancement pada spectrum wavelet ricker untuk mendekati bentuk spectrum wavelet wavez .

(x) Resolusi lapisan tipis yang ditunjukkan oleh BPI pada data riil menunjukkan bahwa BPI mampu cukup baik meresolusi lapisan tipis. Akan tetapi kemenerusan dari hasil BPI belum terlalu bagus akibat dari perhitungan tras dilakukan bertahap setiap trace per trace atau tidak melibatkan keseluruhan trace secara langsung.

\section{Saran}

Saran dari hasil penerapan yang telah dilakukan dan diajukan untuk penelitian selanjutnya adalah:

(i) Optimalisasi penggunaan enhancement pada spectrum amplitude wavelet untuk mendekati spectrum amplitude wavelet wavez pada metode basis pursuit inversion khususnya model reflektor odd disarankan pada penelitian selanjutnya. 
10 Fatahillah dan Winardhi (2017)

\section{REFERENCES}

Zhang, R. dan Castagna, J. 2011. Seismic Sparse-layer Reflectivity Inversion using Basis Pursuit Decomposition. Geophysics, $76,147-158$.

Chopra, S., Castagna, J. dan Portniaguine, O. 2006. Thin-bed reflectivity inversion SEG Technical Program Expanded Abstracts, 2057-2061.

Zhang, R. 2010. Seismic Reflection Inversion by Basis Pursuit Geophysics, 76. 